\title{
Influence of Chitosan Coating on Mechanical Stability of Biopolymer Carriers with Probiotic Starter Culture in Fermented Whey Beverages
}

\author{
Nataša S. Obradović, ${ }^{1}$ Tanja Ž. Krunić, ${ }^{1}$ Kata T. Trifković, ${ }^{2}$ Maja Lj. Bulatović, ${ }^{2}$ \\ Marko P. Rakin, ${ }^{2}$ Marica B. Rakin, ${ }^{2}$ and Branko M. Bugarski ${ }^{2}$ \\ ${ }^{1}$ Innovation Centre of the Faculty of Technology and Metallurgy, University of Belgrade, Karnegijeva 4, 11000 Belgrade, Serbia \\ ${ }^{2}$ Faculty of Technology and Metallurgy, University of Belgrade, Karnegijeva 4, 11000 Belgrade, Serbia
}

Correspondence should be addressed to Nataša S. Obradović; ntomovic@tmf.bg.ac.rs

Received 19 August 2015; Revised 29 September 2015; Accepted 30 September 2015

Academic Editor: Mukund Adsul

Copyright () 2015 Nataša S. Obradović et al. This is an open access article distributed under the Creative Commons Attribution License, which permits unrestricted use, distribution, and reproduction in any medium, provided the original work is properly cited.

\begin{abstract}
The aim of this study was to improve the mechanical stability of biopolymer carriers and cell viability with addition of chitosan coating during fermentation process and product storage. Dairy starter culture $(1 \%(\mathrm{w} / \mathrm{v}))$ was diluted in whey and mixed with sodium alginate solution and the beads were made using extrusion technique. The mechanical stability of coated and uncoated beads, the release behavior, and the viability of encapsulated probiotic dairy starter culture in fermented whey beverages were analyzed. The mechanical properties of the beads were determined according to force-displacement and engineering stress-strain curves obtained after compression testing. It was observed that addition of chitosan as a coating on the beads as well as the fermentation process increased the elastic modulus of the calcium alginate-whey beads and cell survival. The current study revealed that the coating did not significantly improve the viability of probiotics during the fermentation but had an important influence on preservation of the strength of the carrier during storage. Our results indicate that whey-based substrate has positive effect on the mechanical stability of biopolymer beads with encapsulated probiotics.
\end{abstract}

\section{Introduction}

Probiotic bacteria have been incorporated into a wide range of dairy products and orally administrated in various forms, such as food products, capsules, and tablets. The advantage of dairy products is that the addition of probiotics to these products enhances their functionality [1]. The viability of probiotic cells is very important because of their numerous health benefits but the desired number of viable bacteria is difficult to achieve as their number decreases due to the influence of processing, storage, and gastrointestinal conditions. Probiotic bacteria have poor survivability in yoghurt and fermented milk as they do not tolerate exposure to highly acidic and aerated media [2]. Providing probiotic living cells with a physical barrier to resist unfavorable environmental conditions is an approach currently receiving considerable attention as acceptable systems for probiotic products could be achieved [3-5]. Encapsulation is a valuable method that has been recognized for use in the food industry for increasing the viability and stability of probiotic bacteria against unfavorable environmental conditions during processing and storage [6-9]. Polysaccharides, such as alginate, chitosan, gellan gum, and $\kappa$-carrageenan, are the most commonly used materials for the encapsulation of probiotics [1013]. Alginate is a linear polysaccharide consisting of $\beta$-Dmannuronic and $\alpha$-L-guluronic acids, which has been used for the encapsulation of probiotics, proteins, antioxidants, polyphenols, and vitamins $[14,15]$. Some authors reported that the mechanical and chemical stability of alginate beads could be improved by using different coating materials, which beside the protection could enable greater control over bacterial release and improved the viability of encapsulated probiotic organisms $[12,16,17]$. Chitosan, the cationic (14)-2-amino-2-deoxy- $\beta$-D-glucan, is industrially produced from marine and fungal chitin is being used in the food industry. This material is biodegradable, biocompatible, and 
nontoxic. Due to its film forming properties, chitosan has been used for the encapsulation of probiotics and prebiotics, aromatic compounds, enzymes, and antioxidants [18-20]. It has a high modulus along with low elongation-at-break but mixing or copolymerizing chitosan with different polymers can influence its morphology and plasticity [21].

In the recent studies, the textural properties of biopolymer beads of different compositions were tested. These results indicated that differences in mechanical responses to deformation exist because of different crosslinking reactions between biopolymers networks [22].

The textural and physical properties, as well as the entrapment efficiency of the carriers, were greatly affected by the total biopolymer concentration and the employed ratio between both biopolymers [23-25].

The objective of this study was to evaluate the mechanical properties of the beads prepared from a sodium alginate solution containing whey solution with probiotic cells with a chitosan coating formed after the extrusion process. Cell survival during the preparation processes was also investigated. The influence of the fermentation medium on cell viability, mechanical strength, and elastic modulus of the biopolymer carriers before and during storage time was also examined using a Universal Testing Machine (AG-Xplus).

\section{Materials and Methods}

2.1. Materials. Commercially available powdered alginic acid sodium salt (medium viscosity) from brown algae (Sigma Aldrich, USA) was used for the production of the beads. The alginic acid was composed of $61 \%$ mannuronic and $39 \%$ guluronic acid with an $\mathrm{M} / \mathrm{G}$ ratio of 1.56 . Low molecular weight chitosan (Acros Organics, USA) was used as the coating material. Calcium chloride $\mathrm{CaCl}_{2}$ dihydrate (Acros Organics, USA) was used as the gelling cation. Whey and cow milk were obtained from a domestic dairy plant Imlek d.o.o. (Belgrade, Serbia). The chemical composition of whey was total solids $9.8 \pm 0.03 \%(\mathrm{w} / \mathrm{v})$; protein $2.6 \pm 0.012 \%(\mathrm{w} / \mathrm{v})$; fat $1.05 \pm 0.08 \%(\mathrm{w} / \mathrm{v})$; and lactose $5.6 \pm 0.114 \%(\mathrm{w} / \mathrm{v})$. The $\mathrm{pH}$ value of the whey before fermentation was 6.4. The chemical composition of the milk was fat $0.5 \%(\mathrm{w} / \mathrm{v})$; proteins $3.1 \%(\mathrm{w} / \mathrm{v})$; carbohydrates $4.7 \%(\mathrm{w} / \mathrm{v})$; and calcium $0.12 \%(\mathrm{w} / \mathrm{v})$. The whey and cow milk were pasteurized at $60^{\circ} \mathrm{C}$ for $60 \mathrm{~min}$ and cooled to room temperature.

2.2. Preparation of Cell Culture. A freeze-dried dairy starter culture known as "Lactoferm ABY- 6" (containing Streptococcus salivarius ssp. thermophilus, Lactobacillus delbrueckii ssp. bulgaricus, Lactobacillus acidophilus, and Bifidobacterium bifidum) was supplied by Biochem S.R.L. (Monterotondo, Roma, Italy). For all experiments, the cell-whey suspension was prepared by dissolving $1.0 \%(\mathrm{w} / \mathrm{v})$ of frozen starter culture in whey.

\subsection{Encapsulation of Probiotics}

2.3.1. Preparation of the Beads. Sodium alginate suspension was mixed with cell-whey suspension in the ratio $1: 1(\mathrm{v} / \mathrm{v})$.
The alginate beads were made by extruding the alginatecell suspension into $2.0 \%(\mathrm{w} / \mathrm{v})$ of calcium chloride using a syringe pump (Racel, Scientific Instruments, Stamford, CT, USA). Alginate-cell suspension contains $1.70 \%(\mathrm{w} / \mathrm{v})$ sodium alginate. Ca-alginate beads were obtained at a collecting distance of $3 \mathrm{~cm}$ between the blunt stainless steel needle tip (18 gauges) and the calcium chloride solution. After collection, the beads were allowed to harden for $30 \mathrm{~min}$. The beads were separated by filtration, transferred to a sterile Petri dish, and stored at $4 \pm 1^{\circ} \mathrm{C}$ in $0.2 \%(\mathrm{w} / \mathrm{v})$ yeast extract solution [26].

2.3.2. Coating of Alginate Beads with Chitosan. The chitosan and sodium alginate solutions were prepared according to the method of Zhou et al. [27]. Beads with chitosan coating were prepared as follows: the alginate beads were immersed in $100 \mathrm{~mL}$ of chitosan solution $\left(4 \mathrm{~g} \mathrm{~L}^{-1}\right)$, shaken on an orbital shaker at $100 \mathrm{rpm}$ for $40 \mathrm{~min}$ for coating, and rinsed with sterile water to remove the excess chitosan. All steps were performed under aseptic conditions.

2.4. Fermentation. Experiments were conducted in $100 \mathrm{~mL}$ Erlenmeyer flasks containing $50 \mathrm{~mL}$ of medium $(70 \%$ pasteurized whey and $30 \%$ milk). Based on preliminary experiments (data not shown) 30\% of milk was used for beverage formulation as concentration that is appropriate for sensory quality improvement. Samples were inoculated by adding $6 \%(\mathrm{w} / \mathrm{v})$ of encapsulated starter culture. The fermentation was realized at $42^{\circ} \mathrm{C}$. During the incubation, samples were taken every $2 \mathrm{~h}$ for the determination of the $\mathrm{pH}$ value. The fermentations were performed until a $\mathrm{pH}$ of 4.6 was attained and the stopped by rapid cooling. After the fermentation, samples were stored at $4 \pm 1^{\circ} \mathrm{C}$ for 21 days to determine the viability of the cells and the mechanical stability of the beads.

2.5. Cell Release during the Fermentation. The influence of the alginate concentration and chitosan on the encapsulation efficiency was performed by determination of the viable cell count (log CFU mL $\mathrm{mL}^{-1}$ ) and cell release from the beads. Prepared beads $(1 \mathrm{~g})$ were dissolved in sterile sodium citrate solution $(2.0 \%(\mathrm{w} / \mathrm{v}))$ by gently shaking at room temperature for $5 \mathrm{~min}$. The cell release was determined based on the quotients of the number of free cells in the fermentation medium (CFU $\mathrm{mL}^{-1}$ ) and the total number of free (CFU $\mathrm{mL}^{-1}$ ) and encapsulated cells (CFU g ${ }^{-1}$ ), as was presented in the literature [26].

\subsection{Analytical Methods}

2.6.1. Enumeration of the Encapsulated Probiotic Bacteria. For quantitative measurements of cell viability, it was necessary to liquefy the beads and release the encapsulated probiotic cells. The beads were dissolved in sterile sodium citrate solution $(2.0 \%(\mathrm{w} / \mathrm{v}))$ by gently shaking at room temperature. The number of $S$. thermophilus cells was determined by the pour plate counting method on M17 agar. The number of viable cells L. bulgaricus, L. acidophilus, and B. bifidum was determined by the pour plate counting method on MRS agar [28]. 


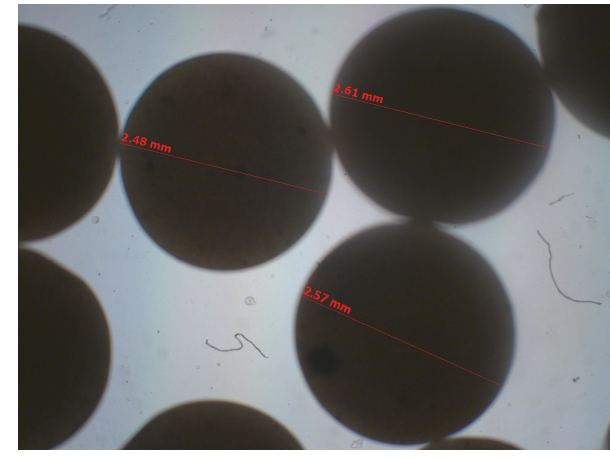

(a)

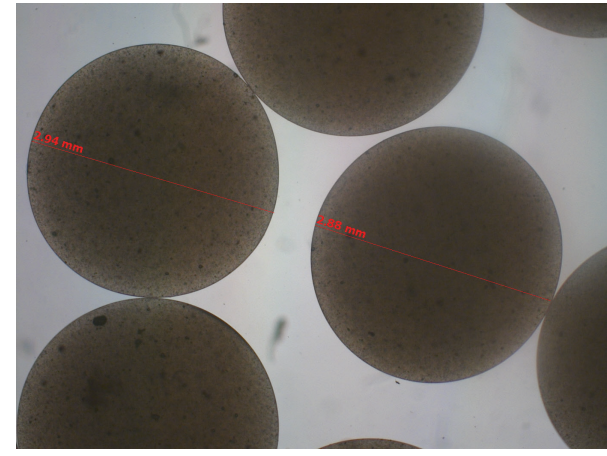

(b)

FIgURE 1: The size of the beads measured using optical microscopy, $5 \times 10$ : (a) alginate beads and (b) alginate beads coated with chitosan.

The results are presented as the total number of viable cells on both substrate (M17 and MRS) and cell number expressed in $\log \left(\mathrm{CFU} \mathrm{mL} \mathrm{m}^{-1}\right)$ for free cells and $\log \left(\mathrm{CFU} \mathrm{g} \mathrm{g}^{-1}\right)$ for encapsulated cells.

2.6.2. Optical Microscopy. The beads shape and existence of aggregates were examined after the encapsulation process using an optical microscope. The diameters of randomly selected wet beads in distilled water were measured by optical microscopy (Carl Zeiss Microscopy GmbH, UK) using a magnification of $5 \times 10$. The average diameter was calculated from the measurements of 30 beads.

2.6.3. Scanning Electron Microscopy. Scanning electron microscopy (SEM) was used to analyze the morphology of the Ca-alginate beads according to the method of Stojkovska et al. [29]. Samples were fixed on a sample holder and visualized using a TESCAN MIRA3 XMU SEM (USA Inc., Cranberry Twp, PA, USA), operated at $20 \mathrm{keV}$.

2.6.4. Mechanical Properties of the Beads. Compression tests of single beads submerged in distilled water were performed using Universal Testing Machine, AG-Xplus (Shimadzu, Japan), equipped with a $100 \mathrm{~N}$ force load cell (force range from 0.01 to $100 \mathrm{~N}$ ). The compression was performed up to $30 \%$ sample deformation (ratio of displacement to initial bead diameter) at a compression speed of $1 \mathrm{~mm} / \mathrm{min}$ and ambient temperature of $25 \pm 1^{\circ} \mathrm{C}$ according to the method described in a previous work [30]. During the compression test, a single bead was submerged in distilled water in a Petri dish and placed on a flat plate. The distance between the plate $(50 \mathrm{~mm}$ in diameter) position at a given deformation and the plate at the first contact with the bead was measured. Thirty beads from each sample were compressed and automatic detection of the contact between plate and bead was performed with a contact force of $0.1 \mathrm{~N}$ under identical conditions. The values of elastic modulus and maximal forces were determined using the force-displacement and engineering stress-strain curves (in the remaining text, stress-strain curves).
2.6.5. Fourier Transform Infrared Spectroscopy (FTIR). FTIR spectra of freeze-dried alginate beads before and after fermentation were analyzed in the wavenumber region of 4000 to $400 \mathrm{~cm}^{-1}$. FTIR was used to verify the chemical interaction between alginate and the fermentation medium (FTIR spectrometer Bomem MB, series Hartmann \& Braun).

2.6.6. Statistical Analysis. The experiments were performed in triplicate. All values are expressed as mean \pm standard deviation. Mean values were analyzed using one-way ANOVA. The Tukey post hoc test was performed for means comparison [Origin Pro 8 (1991-2007) computer package; Origin Lab Co., Northampton, MA, USA]. Data were considered significantly different when $P<0.05$. The mean values of the mechanical properties of the beads were determined using equipment software, TRAPEZIUMX 1.13.

\section{Results and Discussion}

3.1. Size, Shape, and Morphology of the Beads. The mean diameter of the formed Ca-alginate beads was $2.60 \pm$ $0.025 \mathrm{~mm}$. The shape of the beads did not change with the addition of chitosan and the average size of the beads with coating was $2.95 \pm 0.11 \mathrm{~mm}$, as shown in Figure 1 .

From the SEM images of cross sections of the sample, encapsulated rod-shaped and spherical bacteria and their binding in the carrier could be seen. The probiotic bacteria were randomly grouped and placed in the cavity of carriers, as shown in Figure 2.

Void spaces that were recorded around the bacteria in this study were also similar spaces recorded by Sathyabama et al. [31] in SEM micrographs of probiotic strains, namely, Staphylococcus succinus (MAbB4) and Enterococcus faecium (FIdM3) encapsulated in alginate spheres. Based on the observed micrographs, it could be said that the gelation process of alginate beads was disrupted especially in area around the bacteria.

3.2. Influence of the Coating on the Viability of the Encapsulated Probiotic Cells. The initial number of viable cells was 


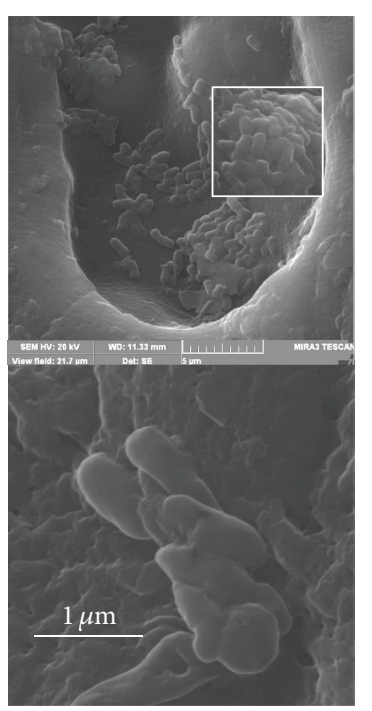

FIGURE 2: SEM micrographs of cross sections of alginate beads with probiotic cells, magnification $10000 \mathrm{x}$.

$7.55 \pm 0.11\left(\log \mathrm{CFU} \mathrm{g} \mathrm{g}^{-1}\right)$ for uncoated beads and $7.59 \pm$ 0.16 ( $\log \mathrm{CFU} \mathrm{g^{-1 }}$ ) for coated alginate beads. During the fermentation, the number of viable cells in the beads without chitosan increased by 0.79 while in the beads with chitosan they increased by $0.88\left(\log \mathrm{CFU} \mathrm{g^{-1 }}\right) \log$ units and reached values of $8.34 \pm 0.14\left(\log \mathrm{CFU} \mathrm{g} \mathrm{g}^{-1}\right)$ and $8.47 \pm 0.29(\log$ CFU g ${ }^{-1}$ ), respectively. Based on these results, it could be concluded that addition of chitosan did not have a statistically significant effect on cell viability during the fermentation.

In addition, comparing the coated and uncoated alginate beads, a significant difference in cell release was observed. The number of cells released into the fermentation medium from the uncoated beads was $5.33 \pm 0.05 \%$, while a slightly lower cell leakage of $4.98 \pm 0.09 \%$ was observed for alginate beads coated with chitosan. This could be explained by the fact that, during the fermentation, electrostatic interaction between alginate carboxylate groups and ammonium chitosan groups leads to a suppression of cell release $[32,33]$. Based on the obtained results, it could be stated that chitosan as coat decreased cell leakage and enhanced retention of the cells within the beads. Influence of chitosan coating on the fermentative activity and survival of encapsulated probiotic cells in simulated gastrointestinal conditions was a subject of our previous work [34]. According to the presented results in mentioned paper, chitosan-coated beads had higher probiotic viable cell count than samples with alginate beads after fermentation, and especially in simulated gastric conditions at $\mathrm{pH} 3.0$ and 2.5. Chávarri et al. [35] also reported that chitosan coating provides better protection of the probiotics in comparison with uncoated microcapsules.

In this study, the influence of the coating on cell viability during storage was also considered. As shown in Figure 3, the chitosan coating improved the viability of the encapsulated probiotics during storage. After 21 days, it was observed that, in the chitosan-coated alginate beads, a greater number of bacteria survived in comparison with those in the uncoated

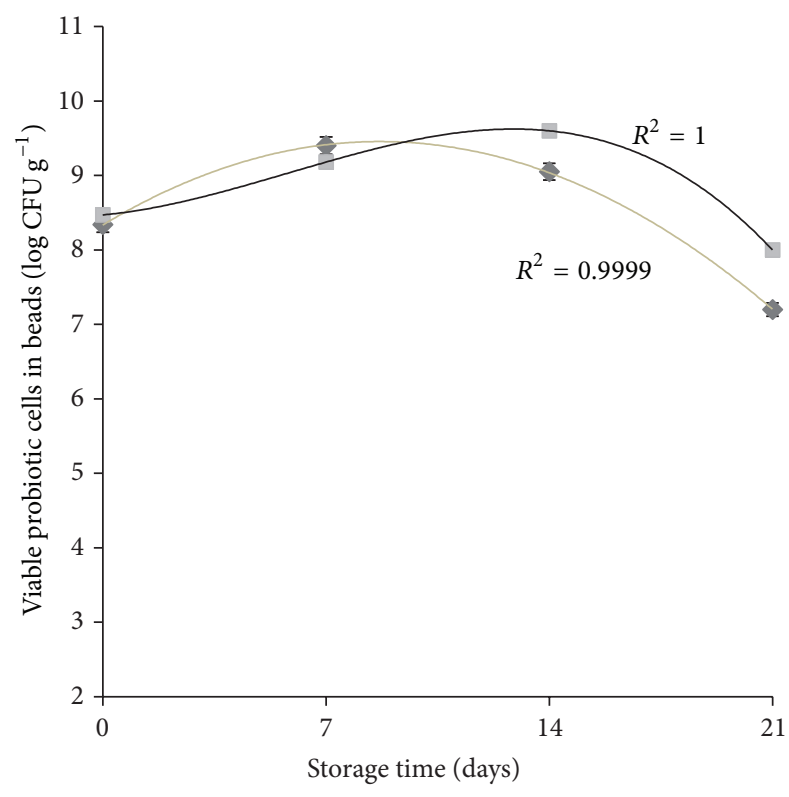

$\begin{array}{lr}\text { Alginate } & \text { Poly. (alginate) } \\ \begin{array}{l}\text { Alginate beads coated } \\ \text { with chitosan }\end{array} & \text { Poly. (alginate beads } \\ \text { coated with chitosan) }\end{array}$

FIGURE 3: Viable cell number of bacteria during 21 days of refrigerated storage, at 7 days of interval for cells in alginate beads (log CFU $\mathrm{g}^{-1}$ ) and coated alginate beads (log CFU g $\left.{ }^{-1}\right)$.

beads, which indicated that the coating improved the viability of the probiotic strains. These findings are in agreement with previous results for the encapsulation of the probiotic strain $L$. plantarum in alginate beads coated with chitosan [12]. Thus, the chitosan coating did not adversely influence the growth of the bacteria during fermentation but stimulated their survival during storage.

\subsection{Effect of the Fermentation Process on the Chemical} Structure of the Alginate Beads. The results of FTIR analysis and the position of the characteristic bands are shown in Figure 4 . The band at $3370.2 \mathrm{~cm}^{-1}$ corresponds to stretching vibrations of $-\mathrm{OH}$ linked to $-\mathrm{NH}_{2}$. The band at $1411.5 \mathrm{~cm}^{-1}$ (related to asymmetric COO-stretching vibration) became broader after interaction of beads with fermentation medium [36]. The results showed changes in the peaks of the amino and carboxyl groups before and after fermentation, which indicates ionic interactions between the carbonyl groups of alginate and the amino groups of the proteins. Hydrogels are potential absorbers of ions present in the medium [37]. The diffusion of $\mathrm{Ca}^{2+}$ into the alginate network is confirmed by the shift of the $-\mathrm{C}-\mathrm{O}$ and the $\mathrm{C}-\mathrm{O}-\mathrm{H}$ vibrations to lower frequencies; additionally, spectral changes in the regions of the COO-antisymmetric and symmetric stretching vibrations occurred. The bands around $1400 \mathrm{~cm}^{-1}$ and $1000 \mathrm{~cm}^{-1}$ correspond to $-\mathrm{C}-\mathrm{O},-\mathrm{C}-\mathrm{C}$, and $-\mathrm{C}-\mathrm{OH}$ groups [38].

3.4. Influence of the Fermentation Process, the Coating, and the Storage Time on the Mechanical Stability of the Beads. Mechanical strength and elastic modulus of the carriers with 


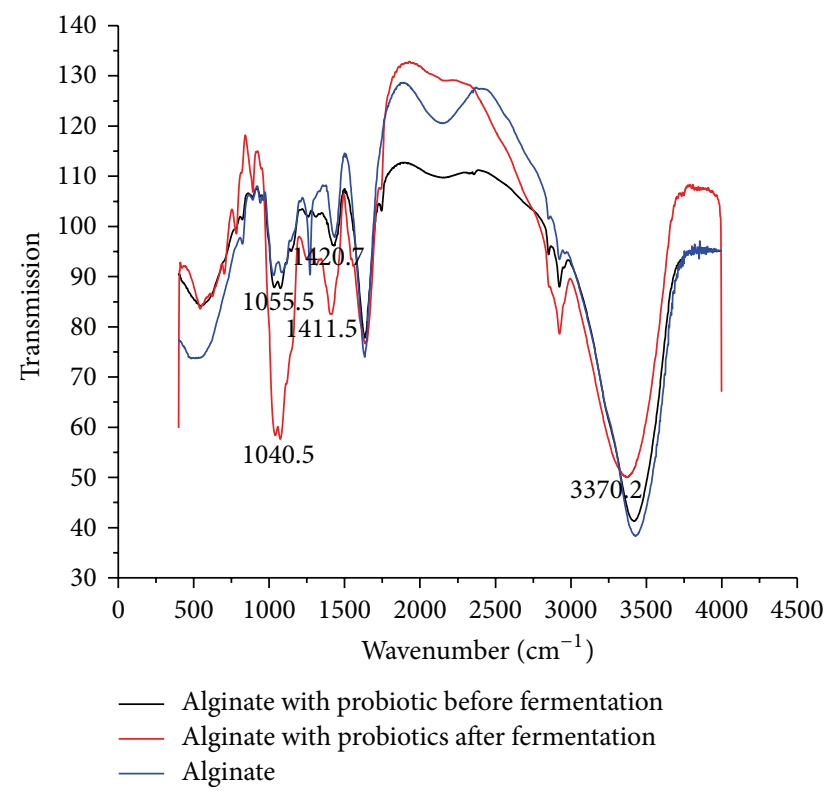

FIGURE 4: FTIR analysis of alginate beads with probiotics before and after fermentation.

probiotic cells were determined with the aim of defining the mechanical stability of the carriers that could be of significance for their further application. The viscoelastic properties of alginate gels have been assessed so far by using static or dynamic compression tests [24,39-42]. The principle of the measurements was to impose a strain on the beads by compression and to measure the corresponding force and the resulting stress.

According to the results presented in Figure 5, it could be seen that the addition of whey with probiotic cells into the sodium alginate solution led to stabilization of the carriers and increased force values. Based on this observation, it could be stated that the calcium ions and proteins from milk and whey had an additional effect on the stability of the carriers. This effect could be explained by the ability of whey proteins to form a gel in the presence of $\mathrm{Ca}^{2+}$ ions. This type of gel, resulting from a dimeric association of guluronic acid regions with $\mathrm{Ca}^{2+}$ in the "egg box" formation, is similar to the alginate gel $[15,43] . \mathrm{pH}$ is also an important factor during the fermentation and has effect on mechanical stability of the beads. The proteins from the milk and whey are $\mathrm{pH}$ dependent and improve gelation process in the $\mathrm{pH}$ range 4,5-5,5 [44]. Comparing the results obtained for the force before and after fermentation, it could be concluded that the fermentation process increased the strength of the alginate beads.

Elastic modulus of the beads was calculated from the slope using least squares regression of the plot of the stress versus strain data obtained from the compression testing. The resulting force-displacement data pairs were converted into corresponding stress and strain values, based on the initial bead diameter. Curves fitting for force-displacement and stress-strain experimental data and quality of the fit $\left(R^{2}>0.99\right)$ are shown in Figure 5. Since alginate particles are viscoelastic, the slopes of the tangents in the elastic parts of the stress-strain curves before and after fermentation were used for the determination of the modulus. Elastic parts of the stress-strain curves (mostly from $10 \%$ to $20 \%$ strain) were selected according to tested degree of recovery after compression and elastic limits studied in literature data [23, 42]. Ca-alginate beads of approximate size $3.01 \pm 0.11 \mathrm{~mm}$ were used for compression testing because of the possibility of comparisons with beads coated with chitosan.

The values of elastic modulus of the alginate beads obtained before the fermentation $(0.059 \pm 0.0029 \mathrm{~N})$ were slightly higher than beads made of calcium alginate without addition of cell-whey suspension $(0.048 \pm 0.0049 \mathrm{~N})$. However, results for the elastic modulus of calcium alginate beads reported by Chan et al. [42] are significantly higher compared to the results in this study. The main difference between the two studies is compression speed used during the assays. Wang et al. [40] demonstrated that the compression speed has influence on the modulus of alginate beads because the wet alginate beads are generally considered to be viscoelastic and may lose liquid under compression. The modulus values of calcium alginate beads (made of medium viscosity alginate without addition of cell-whey suspension, M/G ratio 1.56) obtained at 30\% sample deformation are in good agreement with results reported by Ouwerx et al. [24]. From the force-displacement curves presented in Figure 5, it could be noticed that the presence of chitosan coating reduced the interaction between alginate and the fermentation medium which resulted in a decrease of the measured force of the coated beads after the fermentation process in comparison with the uncoated beads. The results of the elastic modulus of the beads shown in Figure 6 indicate that coating and fermentation increased the modulus of the beads.

The mechanical stability of the beads is important during storage in order to assume the quality and shelf life of fermented beverages. From Figure 7, it could be seen that the maximal forces for alginate beads increased in the first $24 \mathrm{~h}$ because of their direct contact with $\mathrm{Ca}^{2+}$ ions from the fermentation medium. Maximal forces were higher for alginate beads up to the 7th day of storage in comparison with the force for the coated beads. After 1 day, the alginate strength began to decline and this trend continued until the end of the storage. On the other hand, the strength of chitosan-coated beads increased up to the 7 th day when it began to decrease because of intensive cells growth in the cavity of the material and erosion of the bead network. Based on the results, chitosan as a coating material contributed significantly to the preservation of the strength of the carrier during the storage.

\section{Conclusions}

The probiotic starter culture was successfully encapsulated in uncoated and coated alginate beads prepared by the extrusion method. The present study showed that the fermentation process improved the mechanical stability of the biopolymer beads because of the presence of calcium ions and proteins from the milk and whey in the fermentation medium. According to the obtained results, the presence of the chitosan coating improved the carrier strength during storage. Chitosan enables the physical isolation of bacteria from the 


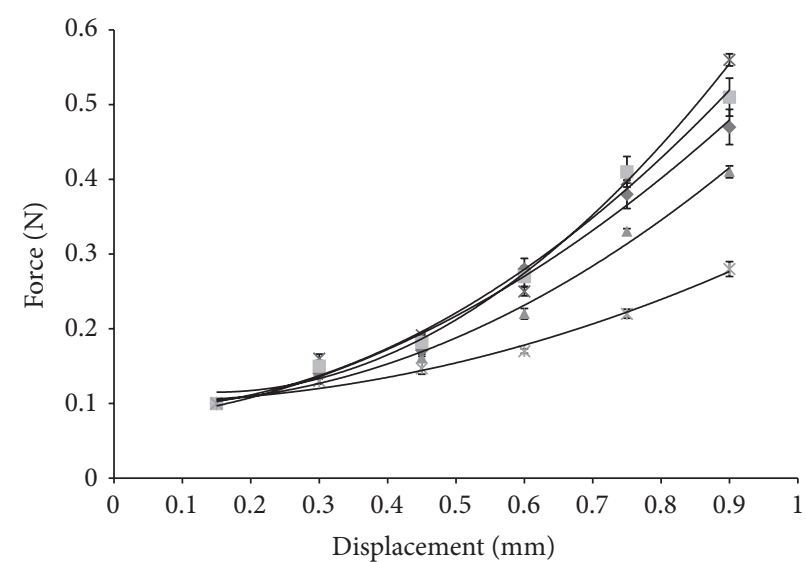

$\Delta$ Alginate $1.7 \%$ before fermentation

- Alginate $1.7 \%$ after fermentation

* Pure alginate $1.7 \%$

$\times$ Alginate $1.7 \%$ (coated with chitosan) before fermentation

Alginate $1.7 \%$ (coated with chitosan) after fermentation

(a)

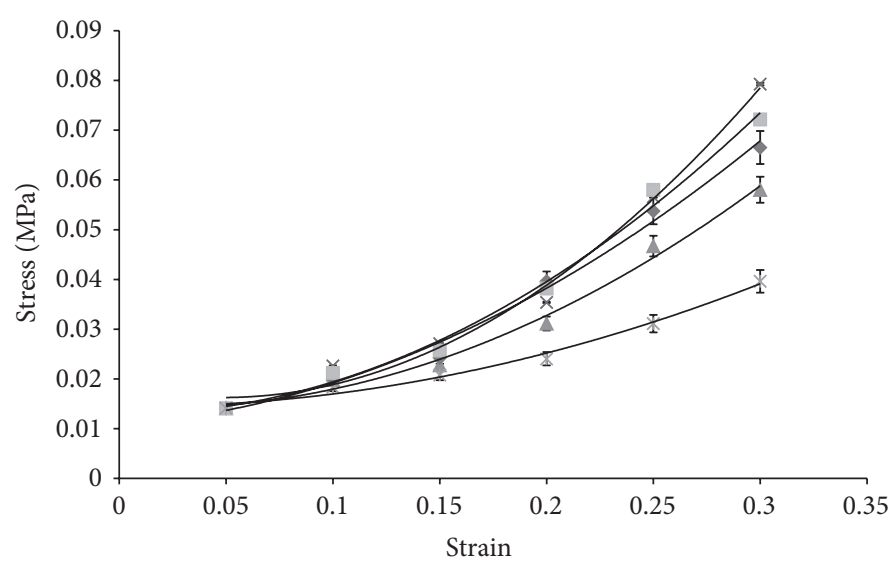

$\triangle$ Alginate $1.7 \%$ before fermentation

- Alginate $1.7 \%$ after fermentation

* Pure alginate $1.7 \%$

$\times$ Alginate $1.7 \%$ (coated with chitosan) before fermentation

- Alginate $1.7 \%$ (coated with chitosan) after fermentation

(b)

FiguRE 5: Comparison of the force-displacement (a) and stress-strain (b) polynomial fitted curves of the biopolymer carriers before and after the fermentation process ( $30 \%$ deformation, compression speed $1 \mathrm{~mm} / \mathrm{min}$, and means values $\pm \mathrm{SD}, n=30$ ).

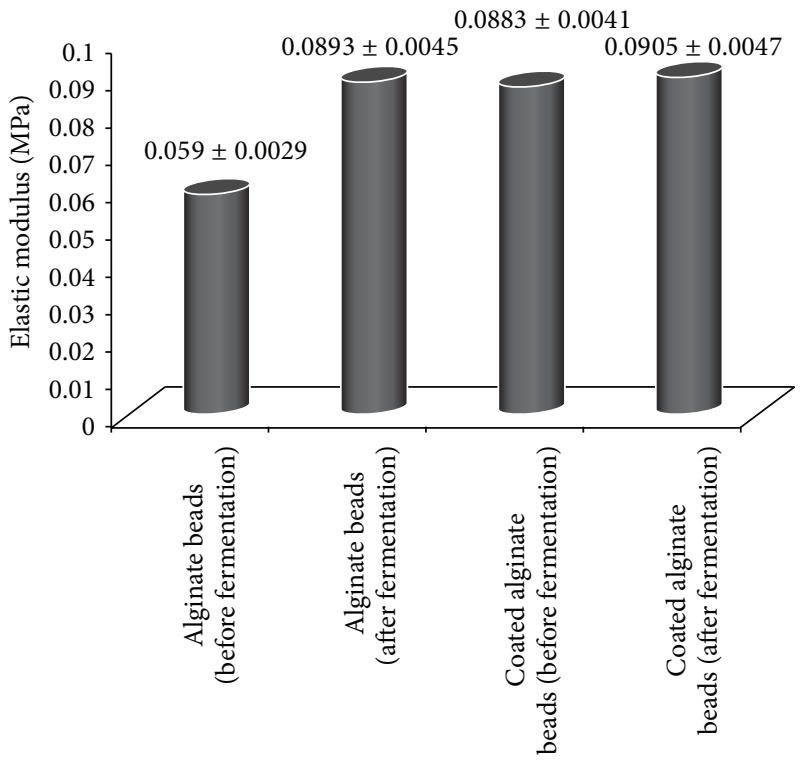

FIGURE 6: Elastic modulus of alginate beads with encapsulated probiotics before and after the fermentation process for $30 \%$ sample deformation (means values $\pm \mathrm{SD}, n=30$ ), alginate concentration $1.7 \%(\mathrm{w} / \mathrm{v})$.

external environment and decreases cell release during the fermentation. The results also indicate that fermentation increased the maximal force in comparison with freshly made uncoated beads with probiotic cells (before fermentation) and extended the shelf life of the product. We have concluded that whey-based fermentation medium had a positive effect on

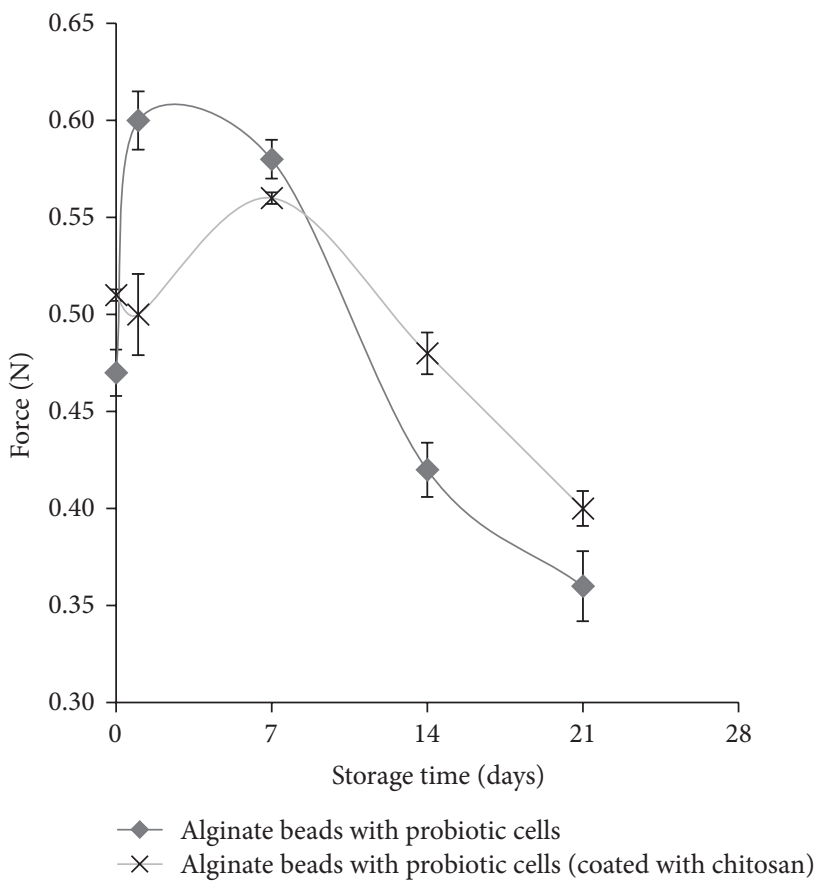

FIGURE 7: Influence of the chitosan coating on mechanical strength of the beads (alginate concentration $1.7 \%(\mathrm{w} / \mathrm{v})$, means $\pm \mathrm{SD}, n=$ $30)$.

the stability of the material for encapsulation of probiotics, which is a very significant finding for the future applications of whey-based fermentation medium in combination with biopolymer beads for the production of fermented beverages. 


\section{Conflict of Interests}

The authors declare that there is no conflict of interests regarding the publication of this paper.

\section{Acknowledgments}

The authors gratefully acknowledge the support from the Ministry of Education, Science and Technological Development of the Republic of Serbia through Projects III 46010 and ON 174004. In addition, the authors would like to give special thanks to the Shimadzu Branch Belgrade (Shimadzu Corporation, Japan) for the technical support during the experiments and Maja Vukašinović-Sekulić, Ph.D., Assistant Professor, University of Belgrade, Faculty of Technology and Metallurgy, for the pictures from the optical microscope, as well as Đordje Veljović, Ph.D., for the SEM measurements.

\section{References}

[1] E. Weichselbaum, "Probiotics and health: a review of the evidence," Nutrition Bulletin, vol. 34, no. 4, pp. 340-373, 2009.

[2] P. Muthukumarasamy, P. Allan-Wojtas, and R. A. Holley, "Stability of Lactobacillus reuteri in different types of microcapsules," Journal of Food Science, vol. 71, no. 1, pp. M20-M24, 2006.

[3] J. Burgain, C. Gaiani, M. Linder, and J. Scher, "Encapsulation of probiotic living cells: from laboratory scale to industrial applications," Journal of Food Engineering, vol. 104, no. 4, pp. 467-483, 2011.

[4] C. P. Champagne and K. Kailasapathy, "Encapsulation of probiotics," in Delivery and Controlled Release of Bioactives in Foods and Nutraceuticals, N. Garti, Ed., pp. 344-369, Woodhead Publishing, Cambridge, UK, 2008.

[5] D. Poncelet, C. Dreffier, P. Subra-Paternault, and T. F. Vandamme, "Introduction aux techniques de microencapsulation," in Microencapsulation: Des Sciences aux Technologies, T. Vandamme, D. Poncelet, and P. Subra-Paternault, Eds., pp. 3-7, Ed. Tec \& doc, Paris, France, 2007.

[6] G. K. Gbassi, T. Vandamme, S. Ennahar, and E. Marchioni, "Microencapsulation of Lactobacillus plantarum spp. in an alginate matrix coated with whey proteins," International Journal of Food Microbiology, vol. 129, no. 1, pp. 103-105, 2009.

[7] L.-E. Shi, Z.-H. Li, D.-T. Li et al., "Encapsulation of probiotic Lactobacillus bulgaricus in alginate-milk microspheres and evaluation of the survival in simulated gastrointestinal conditions," Journal of Food Engineering, vol. 117, no. 1, pp. 99104, 2013.

[8] K. Sultana, G. Godward, N. Reynolds, R. Arumugaswamy, P. Peiris, and K. Kailasapathy, "Encapsulation of probiotic bacteria with alginate-starch and evaluation of survival in simulated gastrointestinal conditions and in yoghurt," International Journal of Food Microbiology, vol. 62, no. 1-2, pp. 47-55, 2000.

[9] M. K. Tripathi and S. K. Giri, "Probiotic functional foods: survival of probiotics during processing and storage," Journal of Functional Foods, vol. 9, no. 1, pp. 225-241, 2014.

[10] N. Kamalian, H. Mirhosseini, S. Mustafa, and M. Y. A. Manap, "Effect of alginate and chitosan on viability and release behavior of Bifidobacterium pseudocatenulatum G4 in simulated gastrointestinal fluid," Carbohydrate Polymers, vol. 111, pp. 700-706, 2014.
[11] F. Nazzaro, F. Fratianni, R. Coppola, A. Sada, and P. Orlando, "Fermentative ability of alginate-prebiotic encapsulated Lactobacillus acidophilus and survival under simulated gastrointestinal conditions," Journal of Functional Foods, vol. 1, no. 3, pp. 319323, 2009.

[12] I. Trabelsi, D. Ayadi, W. Bejar, S. Bejar, H. Chouayekh, and R. Ben Salah, "Effects of Lactobacillus plantarum immobilization in alginate coated with chitosan and gelatin on antibacterial activity," International Journal of Biological Macromolecules, vol. 64, pp. 84-89, 2014.

[13] C. Wandrey, A. Bartkowiak, and S. E. Harding, "Materials for encapsulation," in Encapsulation Technologies for Active Food Ingredients and Food Processing, N. J. Zuidam and V. C. Nedovic, Eds., pp. 31-100, Springer, New York, NY, USA, 2010.

[14] N. T. Annan, L. T. Hansen, and A. D. Borza, "Encapsulation in alginate-coated gelatin microspheres improves survival of the probiotic Bifidobacterium adolescentis 15703T during exposure to simulated gastro-intestinal conditions," Food Research International, vol. 41, no. 2, pp. 184-193, 2008.

[15] S. Wichchukit, M. H. Oztop, M. J. McCarthy, and K. L. McCarthy, "Whey protein/alginate beads as carriers of a bioactive component," Food Hydrocolloids, vol. 33, no. 1, pp. 66-73, 2013.

[16] M. T. Cook, G. Tzortzis, D. Charalampopoulos, and V. V. Khutoryanskiy, "Microencapsulation of probiotics for gastrointestinal delivery," Journal of Controlled Release, vol. 162, no. 1, pp. 56-67, 2012.

[17] W. Krasaekoopt, B. Bhandari, and H. Deeth, "The influence of coating materials on some properties of alginate beads and survivability of microencapsulated probiotic bacteria," International Dairy Journal, vol. 14, no. 8, pp. 737-743, 2004.

[18] M. Chávarri, I. Marañón, R. Ares, F. C. Ibáñez, F. Marzo, and M. D. C. Villarán, "Microencapsulation of a probiotic and prebiotic in alginate-chitosan capsules improves survival in simulated gastro-intestinal conditions," International Journal of Food Microbiology, vol. 142, no. 1-2, pp. 185-189, 2010.

[19] M. G. Žuža, B. M. Obradović, and Z. D. Knežević-Jugović, "Hydrolysis of penicillin G by penicillin G acylase immobilized on chitosan microbeads in different reactor systems," Chemical Engineering \& Technology, vol. 34, no. 10, pp. 1706-1714, 2011.

[20] K. T. Trifković, N. Z. Milašinović, V. B. Djordjević et al., "Chitosan microbeads for encapsulation of thyme (Thymus serpyllum L.) polyphenols," Carbohydrate Polymers, vol. 111, pp. 901-907, 2014.

[21] E. Brychcy, D. Kulig, A. Zimoch-Korzycka, K. Marycz, and A. Jarmoluk, "Physicochemical properties of edible chitosan/hydroxypropyl methylcellulose/lysozyme films incorporated with acidic electrolyzed water," International Journal of Polymer Science, vol. 2015, Article ID 604759, 10 pages, 2015.

[22] O. Sandoval-Castilla, C. Lobato-Calleros, H. S. García-Galindo, J. Alvarez-Ramírez, and E. J. Vernon-Carter, "Textural properties of alginate-pectin beads and survivability of entrapped $L b$. casei in simulated gastrointestinal conditions and in yoghurt," Food Research International, vol. 43, no. 1, pp. 111-117, 2010.

[23] G. Kostov, M. Angelov, I. Mihaylov, and D. Poncelet, "Mechanical properties of Ca-alginate beads for ethanol fermentation with immobilized yeast," Revue de Génie Industriel, vol. 5, pp. 25-35, 2010.

[24] C. Ouwerx, N. Velings, M. M. Mestdagh, and M. A. V. Axelos, "Physico-chemical properties and rheology of alginate gel beads formed with various divalent cations," Polymer Gels and Networks, vol. 6, no. 5, pp. 393-408, 1998. 
[25] W.-P. Voo, P. Ravindra, B.-T. Tey, and E.-S. Chan, “Comparison of alginate and pectin based beads for production of poultry probiotic cells," Journal of Bioscience and Bioengineering, vol. 111, no. 3, pp. 294-299, 2011.

[26] M. Gündüz, Lactic acid production by lactobacillus casei nrrl b441 immobilized in chitosan stabilized Ca-alginate beads [M.S. thesis], Izmir Institute of Technology, Izmir, Turkey, 2005.

[27] Y. Zhou, E. Martins, A. Groboillot, C. P. Champagne, and R. J. Neufeld, "Spectrophotometric quantification of lactic bacteria in alginate and control of cell release with chitosan coating," Journal of Applied Microbiology, vol. 84, no. 3, pp. 342-348, 1998.

[28] L. J. Vrbaški and S. Markov, Praktikum iz mikrobiologije, Prometej, Novi Sad, Serbia, 1993 (Serbian).

[29] J. Stojkovska, D. Kostić, Ž. Jovanović, M. Vukašinović-Sekulić, V. Mišković-Stanković, and B. Obradović, "A comprehensive approach to in vitro functional evaluation of $\mathrm{Ag} /$ alginate nanocomposite hydrogels," Carbohydrate Polymers, vol. 111, pp. 305-314, 2014.

[30] N. S. Tomović, K. T. Trifković, M. P. Rakin, M. B. Rakin, and B. M. Bugarski, "Influence of compression speed and deformation percentage on mechanical properties of calcium alginate particles," Chemical Industry and Chemical Engineering Quarterly, vol. 21, no. 3, pp. 411-417, 2015.

[31] S. Sathyabama, M. Ranjith kumar, P. Bruntha Devi, R. Vijayabharathi, and V. Brindha Priyadharisini, "Co-encapsulation of probiotics with prebiotics on alginate matrix and its effect on viability in simulated gastric environment," LWT_Food Science and Technology, vol. 57, no. 1, pp. 419-425, 2014.

[32] S. Haas, J. Miura-Fraboni, F. Zavala, K. Murata, A. Leone-Bay, and N. Santiago, "Oral immunization with a model protein entrapped in microspheres prepared from derivatized $\alpha$-amino acids," Vaccine, vol. 14, no. 8, pp. 785-791, 1996.

[33] A. J. Ribeiro, C. Silva, D. Ferreira, and F. Veiga, "Chitosanreinforced alginate microspheres obtained through the emulsification/internal gelation technique," European Journal of Pharmaceutical Sciences, vol. 25, no. 1, pp. 31-40, 2005.

[34] T. Ž. Krunić, M. L. Bulatović, N. S. Obradović, M. S. Vukašinović-Sekulić, and M. B. Rakin, "Effect of immobilisation materials on viability and fermentation activity of dairy starter culture in whey-based substrate," Journal of the Science of Food and Agriculture, 2015.

[35] M. Chávarri, I. Marañón, and M. C. Villarán, "Encapsulation technology to protect probiotic bacteria," in Probiotics, E. R. Probiotics, Ed., chapter 23, InTech, Rijeka, Croatia, 2012.

[36] F. Saraei, N. M. Dounighi, H. Zolfagharian, S. M. Bidhendi, P. Khaki, and F. Inanlou, "Design and evaluate alginate nanoparticles as a protein delivery system," Archives of Razi Institute, vol. 68, no. 2, pp. 139-146, 2013.

[37] A. Poreda, T. Tuszyński, M. Zdaniewicz, P. Sroka, and M. Jakubowski, "Support materials for yeast immobilization affect the concentration of metal ions in the fermentation medium," Journal of the Institute of Brewing, vol. 119, no. 3, pp. 164-171, 2013.

[38] G. K. Gbassi, F. S. Yolou, S. O. Sarr, P. G. Atheba, C. N. Amin, and M. Ake, "Whey proteins analysis in aqueous medium and in artificial gastric and intestinal fluids," International Journal of Biological and Chemical Sciences, vol. 6, no. 4, pp. 1828-1837, 2012.

[39] M. Moresi and M. Bruno, "Characterisation of alginate gels using quasi-static and dynamic methods," Journal of Food Engineering, vol. 82, no. 3, pp. 298-309, 2007.
[40] C. X. Wang, C. Cowen, Z. Zhang, and C. R. Thomas, "Highspeed compression of single alginate microspheres," Chemical Engineering Science, vol. 60, no. 23, pp. 6649-6657, 2005.

[41] S. V. Bhujbal, G. A. Paredes-Juarez, S. P. Niclou, and P. De Vos, "Factors influencing the mechanical stability of alginate beads applicable for immunoisolation of mammalian cells," Journal of the Mechanical Behavior of Biomedical Materials, vol. 37, pp. 196-208, 2014.

[42] E.-S. Chan, T.-K. Lim, W.-P. Voo, R. Pogaku, B. T. Tey, and Z. Zhang, "Effect of formulation of alginate beads on their mechanical behavior and stiffness," Particuology, vol. 9, no. 3, pp. 228-234, 2011.

[43] L. Y. Chen and M. Subirade, "Effect of preparation conditions on the nutrient release properties of alginate-whey protein granular microspheres," European Journal of Pharmaceutics and Biopharmaceutics, vol. 65, no. 3, pp. 354-362, 2007.

[44] S. L. Turgeon and M. Beaulieu, "Improvement and modification of whey protein gel texture using polysaccharides," Food Hydrocolloids, vol. 15, no. 4-6, pp. 583-591, 2001. 

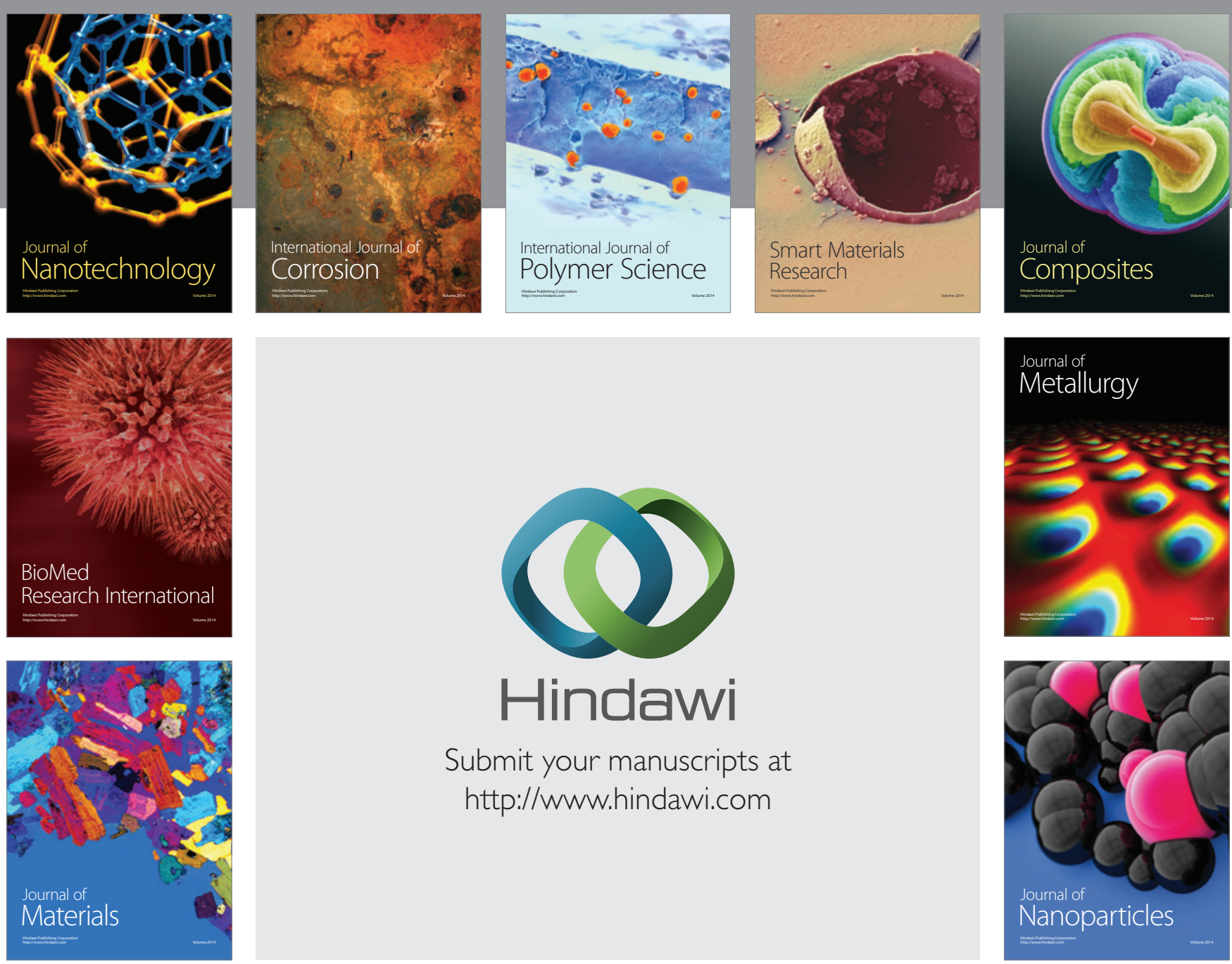

Submit your manuscripts at http://www.hindawi.com
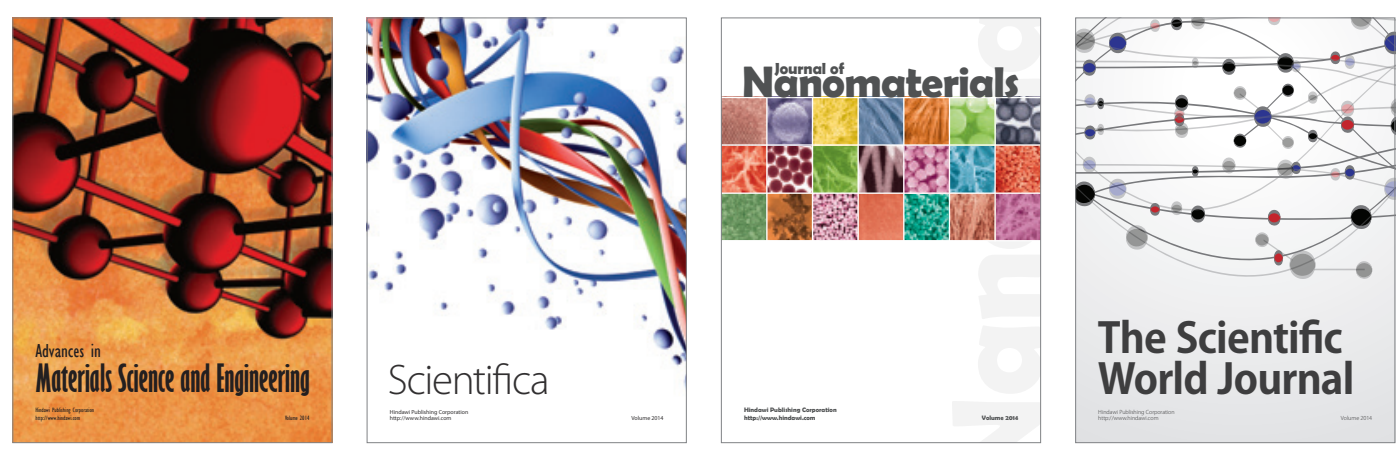

\section{The Scientific World Journal}
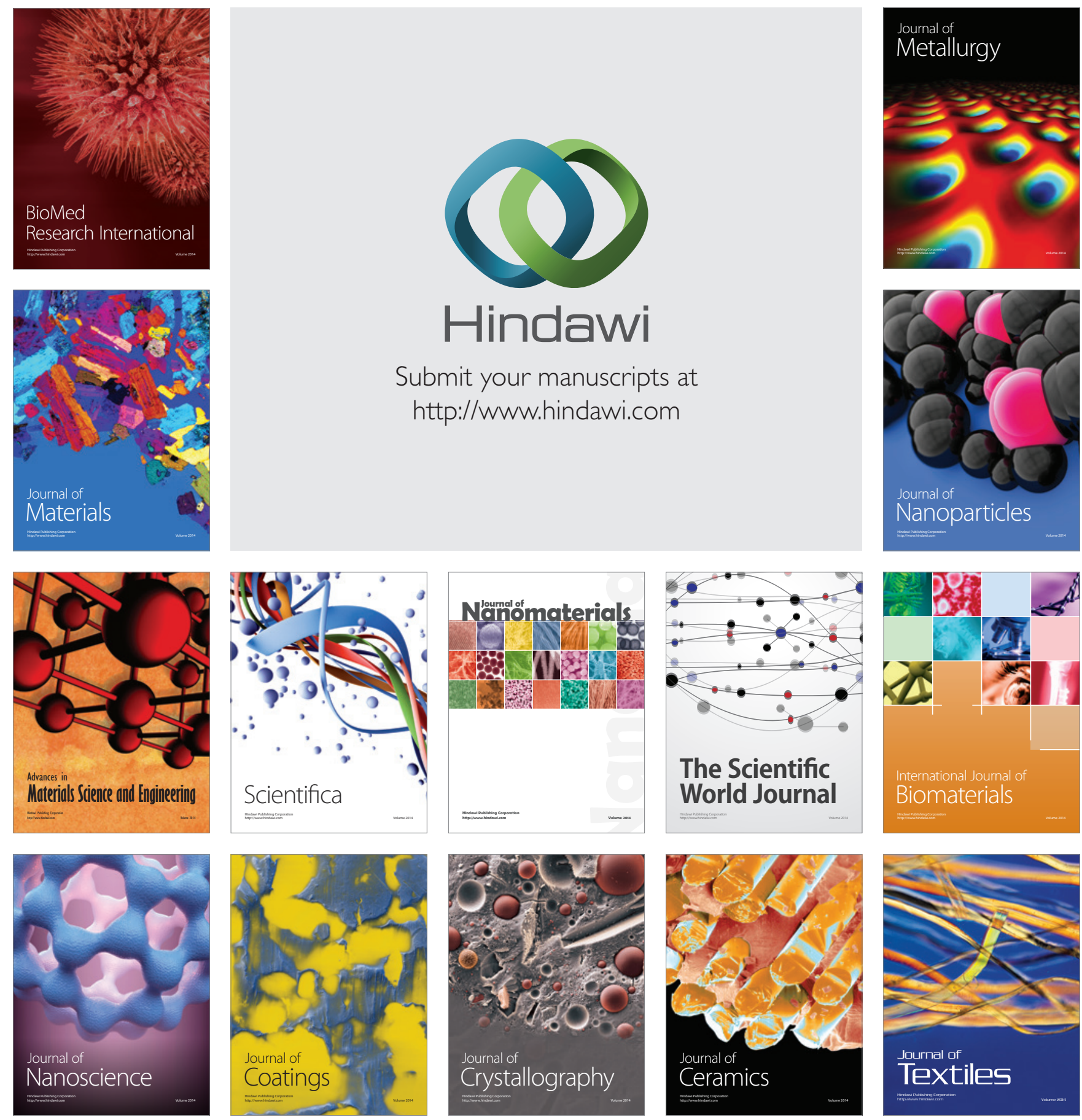